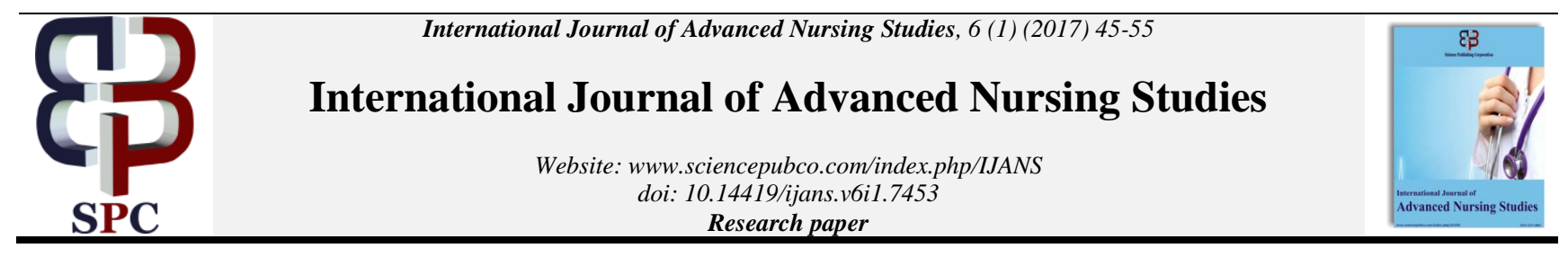

\title{
Work environment characteristics as perceived by nurses in Saudi Arabia
}

\author{
Fatimah Almuhsen ${ }^{1 *}$, Hanan Alkorashy ${ }^{2}$, Fatma Baddar ${ }^{2}$, Abdiqani Qasim ${ }^{1}$ \\ ${ }^{1}$ King Fahad Medical City, KSA \\ ${ }^{2}$ King Saud University, KSA \\ *Corresponding author E-mail: falmuhsen@kfmc.med.sa
}

\begin{abstract}
Summary: The environment that contains; skilled nursing leadership who empowers their staff and improves their autonomy also allowing them to participate in the department and organizational policy, good nurse-doctor relationship, adequate resources and skilled mix staffing, play an essential role to enhance control over nursing practice.

Aim: The aim of this study was to identify nurses' perception of work environment characteristics.

Methodology: A cross-sectional descriptive research design was used throughout this study. A quota sampling technique was used to recruit the participants (staff nurses and first-line nurse managers) from King Fahd Medical City in Saudi Arabia, who was asked to complete the tool; Perceived Environment Scale-Nursing Work Index (PES-NWI).

Findings: 465 nurses participated in this study; 364 were from nurses and 101 from nurse managers, most of the participants were female. Participants were moderately high perceived to their work environments, and there was an association between the characteristics of participants in relation with the work environment.

Conclusion: The current study concluded that the nurses' perception of work environment characteristics was moderately high.
\end{abstract}

Keywords: Work Environment; Nursing Practice; Saudi Arabia.

\section{Introduction}

The term work environment is used to describe the surrounding conditions in which an employee works, it could be composed of physical conditions, such as office lighting, temperature, or equipment, such as computers, it could be also linked to issues such as work processes or procedures; it can involve the social interactions at the workplace, including interactions with peers, subordinates, and managers. A professional practice environment can be defined as the system that supports nurses' control over the delivery of nursing care, the environment in which care is delivered and the features of an organization that assists or limits professional nursing practice (Aiken \& Patrician 2000, Lake 2002). A professional work environment can be described as the system that supports nurses 'control over the delivery of nursing care, the environment in which care is delivered and the characteristics of an organization that facilitates or constrains professional nursing practice (Aiken \& Patrician 2000; Lake 2002). To define the nursing work environment, several researchers are using a set of related concepts, which are described as organizational characteristics influencing nursing practice and known as the 'forces of magnetism' (e.g. Aiken and Patrician 2000; Erickson, Duffy, Gibbons, Fitzmaurice, Ditomassi, and Jones, 2004; Sleutel 2000; Wolf \& Greenhouse 2006).

These characteristics are as follows: autonomy, control over one's practice, status and value of nursing, collaborative governance, professional staff leadership, interdisciplinary communication and teamwork; enhanced internal work motivation, a philosophy of clinical care emphasizing quality, professional development opportunities, supportive management, reasonable workload, flexible scheduling, organizational policies and innovations, workplace safety and delivery of culturally sensitive, competent care to patients of all ethnic groups (Arford \& Zone-Smith 2005; Hall, Doran, Baker, Pink, Sidani, O’Brien-Pallas, Donner, 2003; Wolf \& Greenhouse 2006; Van Bogaert, Meulemans, Clarke, Vermeyen, and Heyning, 2009).

The characteristics listed above have been used in several ways in previous research. Mostly, they have been identified in order to develop practice environment scales (Aiken \& Patrician 2000; Erickson et al. 2004). Prioritize and/or address nursing work-life concerns, develop a framework of nursing work-life or healthy work environments, act as hallmarks or critical factors for assessing a professional nursing practice environment and for achieving work environment excellence (American Association of Colleges of Nursing, 2008). Moreover, they have been regarded as essential attributes for quality care or used to create a program for staff nurses to improve the working environment (Schalk , Bijl, Halfens, Hollands, and Cummings, 2010).

Nurse Manager keeps a central role in creating and supporting a healthy work environment for nurses (Brady, Germain \& Cummings, 2010; Anthony, Standing, Glick, Duffy, Modic, and Dumpe, 2005). A chief nurse executive who advocates for a strong, powerful nursing presence within the organization; is open and communicative; and supports participative management is related to a professional environment that includes clinical practice autonomous and nursing control over practice (Hinshaw, 2002). Upenieks (2003) reported that when the entire executive team and not just the nurse executive, offered support of nursing, a climate was established that endorsed autonomous nursing practice. 
Estabrooks, Tourangeau, Humphrey, Hesketh, Giovannetti, Thomson, Wong, Acorn, Clarke, and Shamian (2002), defined work environment as a set of workplace features that, when present, enable nurses to demonstrate professional practice characterized by decision-making autonomy, clarity of mission, and organizational responsiveness. The impact of the nursing work environment is an important area of nursing research, particularly because the environment relates to patient safety and quality of care (IOM, 2004; American Nurses association, 2011).

Magnet hospitals are popular with nurses since they are characterized by high levels of management support, positive nurse-doctor and nurse-manager relationships, professional responsibility and autonomy (Smith, Tallman, and Kelly, 2006). Most nurses succeed in these settings as workplace empowerment structures enhance nurses' autonomy, control, power, and opportunity (British Columbia Nurses Union, 2011). On the other hand, a powerless nurse is an ineffective nurse.

Today's hospital nurses and administrators need to improve the nursing work environment (Cramer, Staggs, and Dunton, 2014). By treating the nurse practice environment as a complex system, approaches can result in greater nurse professionalism, empowerment and patient safety (Laschinger, Shamian, and Thomson, 2001; Laschinger, Almost, and Tuer-Hodes, 2003; Lin \& Liang 2007). The impact of the nursing work environment to the quality of work experience for nurses and the delivery of quality patient outcomes in acute-care hospitals has increasingly been demonstrated through nursing systems research.

A professional practice environment supports nurses' ability to function at the highest level of clinical practice, to work effectively in an interdisciplinary team of caregivers, and to mobilize resources quickly (Lake, 2007). Nursing work environments with higher levels of employee participation in decision-making and control over working conditions have been associated with increased employee satisfaction and performance, specifically, work environments where nurses report high levels of control over nursing practice have been associated with a number of positive outcomes, including lower staff turnover rates, fewer nurse burnout, and lower patient mortality rates (McClure \& Hinshaw, 2002; Vahey, Aiken, Sloane, Clarke, and Vargas, 2004).

Concomitantly, job-related stress was found creates low selfesteem, mental health imbalances and physical symptoms (Nixon, Mazzola, Bauera, Kruegerc \& Spectora, 2011). Given the global nursing shortage, improving the nursing work environment has become a worldwide issue, in the United States; the task of improving hospital nursing work environments rests primarily with the hospitals themselves. An extensive body of evidence confirms the relationships among positive work environments, positive nurse outcomes of job satisfaction and retention, and positive patient outcomes (Cramer, Staggs \& Dunton, 2014).

Job stress in the practice environment is the strongest predictor of nurses' job dissatisfaction and intent to leave and is linked to the global nursing shortage (Sriratanaprapat, \& Songwathana, 2011). The causes of stress include poor nurse-doctor interactions, staff shortages, patient acuity, shortened length of stay, increased use of new technology (such as computerized documentation), unpredictable schedules, workload and/or workflow(Zangaro \& Soeken, 2007). On the other hand, effective communication (particularly with doctors), control over practice, abilities to make decisions at the bedside, high-functioning teamwork and nurse empowerment were found to increase nurses' job satisfaction and decrease turnover (Kalisch, Curley, and Stefanov, 2007; DiMiglio, Padula, Piatek, Korber, Barrett, Ducharme, \& Corry 2005). Organizational structures, which increase autonomy, lead to higher job satisfaction and retention for nurses (Force, 2005).

A work environment that adopts a collaborative management style recognizes that professionalism, autonomy, and leadership styles are important to the professionalism and role satisfaction of charge nurses. Work environments that focus on a decentralized organizational structure facilitate control over nursing practice by the $\mathrm{CN}$ (Brunoro, 2007).Multiple national and international studies and a Canadian Collaborative Committee (CCC) composed of ten part- ners including: the Canadian Council on Health Services Accreditation (CCHSA), Academy of Canadian Executive Nurses (ACEN), Association of Canadian Academic Healthcare Organizations (ACAHO), Canadian College of Health Service Executives (CCHSE), Canadian Federation of Nurses Unions (CFNU), Canadian Healthcare Association (CHA), Canadian Health Services Research Foundation (CHSRF), Canadian Medical Association (CMA), Canadian Nurses Association (CNA) and the National Quality Institute (NQI) have identified five key attributes that must be in place to ensure a quality practice environment and include; Workload Management: There are sufficient nurses to provide safe, competent and ethical care, Nursing Leadership: There are competent and well-prepared nurse leaders at all levels in the organization, Control over Practice: The nurses have responsibility, authority and accountability for nursing practice, Professional Development: The organization supports and encourages a lifelong learning philosophy and promotes a learning environment and Organizational Support: The organization's mission, values, policies and practices support and value nurses and the delivery of safe and appropriate nursing care (Nursing Association of New Brunkswick, 2011).

A study conducted by McClure Poulin, Sovie, \& Wandelt ,1983 made way for initiating magnet recognition program by The American nurses credentialing center (ANCC) in 1990's focusing on improvising patient care, patient safety and patient experiences by generating a good and healthy work environment for nurses (McClure \& Hinshaw, 2002).

However, the research by Kieft, de Brouwer, Francke, \& Delnoij (2014) threw out interviews to nurses practicing in different centers to evaluate various aspects such as elements corresponding to the eight "essentials of magnetism "aiming to bring awareness in the nurses so as to incorporate these into the nursing practice to bring more positive patient experiences of nursing care, evaluations were made on nursing practice such as clinically competent nurses, collaborative working relationships, autonomous nursing practice, adequate staffing, and control over nursing practice, managerial support and patient-centered culture, the observations from this research have resulted in better understanding of nurses executing their role in achieving positive patient experiences. As part of external accountability, cost-effectiveness and transparency are the main focus in nursing policy nowadays which creating a high administrative workload and pressure to increase productivity. However, despite all the registrations that take place for external accountability, the participants stated that they never monitor care results improvising their own practice since they found themselves lack of autonomy to influence this.

The working environment of nurses is getting global, interest, and concern, because there is a growing consensus that identifying opportunities for improving working conditions in hospitals, it is essential to maintain adequate staffing, high-quality of patients care, nurses' job satisfaction and minimize their retention (Hinno, Partanen, Vehvila-Julkunen, 2012). The hospitals must use an outcome indicator of hospital performance including constant monitoring of nurses perceptions of their work environment (Hinno, Partanen, Vehvila-Julkunen, Aaviksoo, 2009; Aboshaiqah, 2015; Purdy, Laschinger, Finegan, Kerr ,Olivera, 2010). Positive patient outcomes can achieve by a good relationship between the quality of the workplace and nurse work effectiveness, as well as empowered nurses to be satisfied and decrease nursing retention. (Purdy, Laschinger, Finegan, Kerr and Olivera, 2010). Regardless of the total of experience in the profession, empowerment has a strong effect on work arrangement which consequently affects work effectiveness, nurses who involve positively in their work through feelings of strength, loyalty and interest in their work can make a changes to the qualityof nursing work life for others in hospital settings, by motivating their colleagues and making work in this setting attractive to nurses within the system and newcomers to the profession, also, the results deliver initial support for theory-driven strategies to attend to issues in current nursing work environments that must be addressed to confirm that all nurses a positively involved in their work and empowered to 
deliver a high-quality care to the patients (Spence Laschinger, Wilk,Cho and Greco, 2009).

In European, the results of a study conducted in the two countries; Finland and the Netherlands, indicated that there were relationships between nurses' evaluations of their practice environment characteristics and nurse-reported job outcomes (Hinno, Partanen and Vehvila inen-Julkunen, 2012). On the other hand, the finding of Baernholdt \& Mark (2009) study mention that to improve nurse outcomes it is practical to inspect the work environment as part of a general plan and making well support services.

A nurse work environment that supports autonomous nursing practice and nurses who are committed to their care must be part of both rural and urban hospitals plans for modification in order to recruit and maintain nurses (Baernholdt \&Mark, 2009). In a Japanese acute-care setting study they found that nursing practice environment was a significant predictor of patient and organizational outcomes, the study findings support the needs of interventions to improve the nursing practice environment, to improve quality of patient care and ward morale in Japan, the findings also strengthen the need for Japanese policy makers and hospital administrators to improve nurse staffing and working conditions in acute-care settings (Anzai, Douglas, and Bonner, 2014). The positive practice environments increase job satisfaction and lower levels of burnout among critical care nurses.

Furthermore, the key to staff and patient outcome is the positive practice environment in South Africa (Klopper, Coetzee, Pretorius and Bester, 2012). In Saudi Arabia, one study shows that healthy work environments have mutually benefited patients, nurses, nurse managers, health-care providers, the health team, administration, the institution and the community at large, it also showed that there are no initiatives from the hospital administration to improve the work environment. However, the staff nurses must have opportunities to take part in shaping their work environment and each person in the organization should contribute and collaborate for continuous improvement of a healthy work environment (Aboshaiqah, 2015).

\subsection{Nursing participation in hospital affairs}

Magnet hospital research suggested that the arranging of an available nurse leader in the senior management structure of the organization provides the nursing enough power to impact policy decisions or action on concerns related to nurses (McClure \& Hinshaw, 2002). There is a relationship between nursing leadership, workplace settings, and nurses' commitment to the organization thru 217 hospital wards (Laschinger, Finegan, and Wilk, 2009). Van Bogaert et al (2009), Study shows a connected aspect of leadership, the basics of quality nursing and participation in hospital affairs to developed quality of care.

\subsection{Nursing foundations for quality of care}

Patient care quality has been studied in terms of work effectiveness (Laschinger \& Havens, 1996), adverse events; medication errors, nosocomial infections, and patient falls (Laschinger \& Leiter, 2006), medication errors and falls individually (Mark et al., 2009), and nurse reports of patient care quality using a single item measure (Schmalenberg \& Kramer, 2008). The result of a qualitative study done by (Kieft, Brouwer, Francke and Delnoij, 2014) stated that the nurses said they believe there are several elements to improve patient experiences of nursing quality ;clinically competent nurses, collaborative working relationships, adequate staffing, autonomous nursing practice, control over nursing practice, managerial support and patient-centered culture. Moreover, they feel stressed to increase productivity and report a high administrative workload. They stated that to improve patient experiences, the nurses should have autonomy over their own practice.

The quality of patient care is greater when the foundations for quality of care are present in their present job (Anzai et al., 2014). In the USA, the nurses demonstrated that the accessibility of educational chances was related to nurses' perceptions of the quality of care (Ulrich, Lavandero, Hart, Woods, Leggett, \& Taylor, 2006). In Canada, one study shows that nursing foundation for quality of care influenced quality of care over staffing and resource adequacy (Laschinger, 2008).

In Finland, the high standards of nursing care are interrelated to decreased nurse stress, improved job satisfaction, less adverse events for patients and nurses, and enhanced patient satisfaction (Tervo Heikkinen, Partanen, Aalto, \& Vehvilainen-Julkunen, 2008). Global, both patient and nurse outcomes in nursing settings are developed in organizations which are provide professional improvement for nurses and that inspire high principles of nursing within a nursing model of care.

\subsection{Nurse manager ability, leadership, and support of nurses}

Nursing leadership can be evident in the formation of basic organizational supports recognized in the magnet hospital (Aiken, Clarke, Sloane, Lake, \& Cheney, 2008). Strong nursing leadership in the practice area has been known in general nursing research as a significant predictor of better outcomes for nurses and patients (Aiken et al., 2008; Leiter \& Laschinger, 2006). Strong nursing leadership is seen as allowing clinical nurse autonomy, empowerment and best practice over clear management structures and nursing picture (Schmalenberg \& Kramer, 2008).

There is an association between effective nursing leadership and the empowerment of nurses in the practice environment allied with higher job satisfaction (Laschinger, Finegan, Shamian, \& Wilk, 2004). Also, one study shows that registered nurses who reported greater levels of support from their supervisors were less expected to leave their position than were registered nurses who reported lesser levels (Cohen, Stuenkel \& Nguyen, 2009). The importance of leadership concluded the leaders' skills to inspiration other aspects of the work environment, such as staffing \& resources, skill mix, and improved involvement in the organization (Leiter \&Laschinger, 2006).

\subsection{Staffing and resources}

Nurse staffing is complex. Nurse staffing is a matter of main concern globally since its effects the patient safety and quality of care (Hinno, Partanen and Vehvila inen-Julkunen, 2012). Adequate staffing in the workplace result from a balance between supply and demand, which can interaction with the nursing practice environment (Lin, Chiang, \& Chen, 2011). Adequate nurse staffing improves nurses, patients, and organizations outcomes. The improvement of patient outcome, along with shorter lengths of stay can be achieved by increase nursing staffing levels (Dall, Chen, Seifert, Maddox, \& Hogan, 2009).

In California, the result of increased nurses to patients has exposed to have an obvious change in patient outcomes (Seago, 2002). On the other hand, nurses were more dissatisfied when staffing overall was apparent to be inadequate. Insufficient staff and decreases teamwork cause a workload to staff nurses and lead them to be stressed and overwhelmed (Kalisch \&Lee, 2011). In Finland and the Netherlands, there was a significant relationship between nurse staffing and adverse patient outcomes in hospital settings. (Hinno et al., 2012)

A meta-analysis of 28 studies (Kane, Shamliyan, Mueller, Duval, $\&$ Wilt, 2007) found a high degree of stability in the relationships between staffing and skill mix, nurse outcomes i.e. Job satisfaction and burnout, and patient outcomes i.e. Mortality and adverse events. Also, a systematic review of 22 large studies recognized a strong relationship between nurse staffing, skill mix, and patient outcomes (Lankshear, Sheldon, \& Maynard, 2005). Nursing shortages compromise the safety and quality of patient care thus, it is essential that organizational address the factors of nurse and patient outcomes (Anzai, Douglas, and Bonner, 2014).

Rochefort, Buckeridge and Abrahamowicz (2015) study will probably create evidence-based information that will help the managers in making maximum effective use of limited nursing 
resources and in identifying staffing patterns that reduce the risk of adverse events (Rochefort, Buckeridge and Abrahamowicz, 2015). There were generally a simultaneous reduction in nurse staffing and the interrupted work environment for nurses was associated with significant increases in a variety of negative patient outcomes (McCloskey \& Diers, 2005).

\subsection{Nurse-doctor relationships}

The professional relationship between members of healthcare teams is essential; the nurse-doctor relationship is interdependent. Fagin and Garelick (2004), belief in knowledge and responsibility sharing for patient care. Pullon (2008), state three elements that should be demonstrated in the relationship between nurses, doctors, and other health professionals in order to function effectively in delivering health-care, these elements are; respect, trust and competence (Weaver, 2013).

On the other hand, professional relationships between doctors and nurses have often remained realized as problematic (Pullon, 2008). In the United States, a study of general nurses established strong relations between collegial relationships, stress, and nurses' job satisfaction (Manojlovich, 2005). In New Zealand, a survey of general nurses found that positive nurse-doctor relationships were linked with advanced levels of communal functioning, vitality, and mental health (Budge, Carryer, \& Wood, 2003).

In Australian the nurse-doctor relationship in mental health has been linked to the effect nurses have in decisions about patient treatment (Elsom, Happell, \& Manias, 2007). In contrast the other Australian research, state that association was identified between nurse-doctor relationships and nurses' job satisfaction and reported the experience of threats of violence (Duffield, Roche, O'Brien-Pallas, Catling-Paull, \& King, 2009; Roche , Diers, Duffield \& Catling-Paull, 2010).

\section{Methods}

\section{Research Questions}

1) What are the characteristics of the practice environment as perceived by the study's subjects?

2) What is the influence of Subjects' selected characteristics on their perception of characteristics of work environment?

\subsection{Research design}

A cross-sectional correlation descriptive research design was used for this study. A quota sampling technique was used to recruit the participants from KFMC in Saudi Arabia who was asked to complete the tool.

Survey questionnaires were administrated to nurses in the clinical setting of KFMC who have one-year experiences, holding a current nursing license and can read and write in English.

The researcher used a paper and pen instrument that was comprised of three parts: demographic questions that described the subjects, the demographic portion of the survey contained six items that included subject's age, gender, highest educational level, certification, current job position, and current work unit/area, second is (PES-NWI). The researcher's intention was to describe the demographic variable of the sample to assess for any influence on the research findings.

\subsection{Participants}

The participant was all bedside nurses and first-line nurse managers working in the selected setting. For the current study, the sample was drawn from the nurses working in different in-patient wards and units in the selected setting using proportional Quota sampling technique.

\subsection{Inclusion criteria}

The inclusion criteria for participants included: Staff nurses holding a current nursing license, practicing bedside patient care, can read and write in English, employed in current setting for not less than a year. While the inclusion criteria for first line managers was holding a current nursing license, can read and write in English, practicing in a managerial first-line position, employed in the current setting for not less than a year.

\subsection{Sample size}

From the accessible population, all nurse managers $(\mathrm{n}=140)$, and a Quota sample of the staff nurses $(n=1134)$ had been considered for data collection. The sample size was calculated using the $\mathrm{G}^{*}$ power 3.0 program. The number of subjects needed to achieve an effect size of 0.3 (medium), a level of significance $(\alpha)$ of .05 , and a test power $(1-\beta)$ of 0.95 was 550 . Since the inclusion of participants was not random (convenience instead), the sample was further increased by $10 \%$ to account for contingencies such as nonresponse and/or potential drop-outs, bringing the final sample size to 600 nurses and 140 nurse managers.

\subsection{Tool}

A self-report questionnaire was adopted and used for collecting data for this study. The questionnaire comprises Two main parts; First part: Selected Demographic and occupational Characteristics: a set of selected demographic contained six items, subject's age, gender, highest educational level, certification, current job position, current work unit/area and years of experience. Second part is "Nursing Practice Environment (NPE) scale. This scale was derived from Perceived Environment Scale-Nursing Work Index (PES-NWI) (Lake, 2002). It was developed to measure the hospital nursing practice environment, based on the Nursing Work Index (Kramer \& Hafner, 1989) that was originally developed to capture the organizational characteristic of work setting environment.

PES-NWI was used in this study because; it has been shown to be a valid and reliable tool for the measurement of the hospital nursing practice environment (Lake, 2002) with (Cronbach's alpha of the total scale $=0.948)$. Nursing work environment scale; the scale from (1) strongly agree to (5) strongly disagree; scale $(1-2.3)$ consider high perception, scale (2.3-3.6) consider moderate perception, and scale (3.6-5) consider low perception. The scale consists 5 subscale/category; 1 . Nurse Participation in hospital affaires contain (9) questions. 2. Nursing Foundation for Quality of care, contains (10) questions. 3. Nurse Manager Ability, Leadership, and support of nurses contain (5) questions.4. Staffing And Resource Adequacy, contain (4) questions. 5. Collegial NursePhysician Relations which contain 3 questions.

\subsection{Pilot study, tools validity, and reliability}

To establish face validity, the author invited an expert in the field of research and asked them to read through the questionnaires. These experts evaluated the questionnaire using jury form; whether the questions effectively capture the topic under investigation.

The second step was conducting a pilot test of the survey on a subset of the intended population (staff nurses and nurses' managers). A recommendation on sample size for pilot testing was 23 ; these questionnaires were distributed to the different units in the study setting, 18 of the questionnaires was distributed to the staff nurses while the five of the questionnaire was distributed to the nurses managers. The participants were asked to complete the questionnaire and give feedback about the clarity and meaningfulness of all items. It was found that all items were appropriately and similarly understood by respondents. After the author collected the pilot data, the responses were entered into a spreadsheet and, the data cleaned. To identify the underlying components and what factors are being measured by the survey questions, the author used principal components analysis. 


\subsection{Assessing the reliability of the instrument}

The author checked internal consistency as followed; Cronbach's alpha was calculated to assess the degree of internal consistency and homogeneity between the items. The minimum score of 0.70 is required to support claims of internal consistency. The Cronbach's alpha was $96.1 \%$.

\subsection{Method of data collection}

The questionnaires were distributed to the nurses directly while they were on duty; by meeting the head nurse in each unit and explained to them the purpose of study and informed participants that they could choose to withdraw from the study at any time without consequences, with maintain the confidentiality of the participant's identities through the data collection process. Questionnaires were then collected from the head nurses in all units 600 questionnaires were distributed to the nurses and 140 questionnaires distributed to the nurse managers.

\subsection{Ethical considerations}

The authors acknowledged the contribution of people in the study. Participants were ensured that no personal information would be revealed. No names would be mentioned in any report. The permission to use questionnaire was sent to the author and responded by approval to use the questionnaire. The researcher obtained both Nursing Research Committee Approval and' Institutional Review Board (IRB) approval prior to data collection.

\subsection{Statistical analysis}

To address questions one; descriptive statistics was used to describe the nurses' perception to NWE. The descriptive statistics included (mean and standard deviation). Questions two will be addressed by using (Independent sample t-test) for measuring tow variables, this test is more powerful as long as distribution for each group is normal or the sample size for each group $\geq 30$, and One-way ANOVA for more than two variables.

\section{Results}

\subsection{Response rate}

From all questionnaire sheets distributed $(n=740), 663$ sheets had returned, with a response rate of $89.6 \%$. From these returned sheets, 198 sheets had been excluded for either incompletion or invalid responses. The final number of survey sheets had been used for analysis and result acquisition was 360 from nurses and 105 from nurse managers, a total of 465 sheets.

i). Selected characteristics of the participants

Most of the participants age were between $20-40$ yrs. 189 (40.6\%), since the majority 438 (94\%) of participants were female, we assumed that the perception of control was mainly from female participants. There was only $(1 \%)$ doctorate degree holder and 13 master degree, we decided to combine them. Most of the participants were Bachelor degree 307 (66\%), followed by diploma 144 (31\%). Most of participants $327(70.5 \%)$ did not have a special certification while $137(29.5 \%)$ have a special certificate. The total number of staff nurses who participated in this study were 360 $(77.4 \%)$ were the first line nurses managers numbers were 105 $(22.58 \%)$. Most of participant $182(39 \%)$ from the general ward, $151(32 \%)$ from the critical area, $92(19 \%)$ from specialized area, while $40(8.6 \%)$ from emergency area. Most of participants 215 (46\%) had experience from 5 to 10 years; followed by $150(32 \%)$ 10 to 20 years, $60(12 \%)$ have less than 5 years' experience and 40 $(8.6 \%)$ had more than 20 years' experience.
Table 1: Basic Characteristics of the Participants $(\mathrm{N}=465)$

\begin{tabular}{|c|c|c|c|}
\hline \multicolumn{2}{|c|}{ Demographic characteristics' } & \multirow{2}{*}{$\begin{array}{l}\mathrm{N} \\
166\end{array}$} & \multirow{2}{*}{$\frac{\text { Percentage }}{35.70 \%}$} \\
\hline \multirow{5}{*}{ Age } & $20-30$ & & \\
\hline & $30-40$ & 189 & $40.6 \%$ \\
\hline & $40-50$ & 83 & $17.8 \%$ \\
\hline & $>50$ & 27 & $5.8 \%$ \\
\hline & Total & 465 & $100 \%$ \\
\hline \multirow{3}{*}{ Gender } & Female & 438 & $94.2 \%$ \\
\hline & Male & 27 & $5.8 \%$ \\
\hline & Total & 465 & $100 \%$ \\
\hline \multirow{4}{*}{$\begin{array}{l}\text { Highest Educational } \\
\text { Level }\end{array}$} & Bachelor's & 307 & $66 \%$ \\
\hline & Diploma & 144 & $31 \%$ \\
\hline & Higher education & 14 & $3 \%$ \\
\hline & Total & 465 & $100 \%$ \\
\hline \multirow{5}{*}{ Certification } & No & 327 & $70.3 \%$ \\
\hline & Yes & 137 & $29.5 \%$ \\
\hline & Total & 464 & $99.8 \%$ \\
\hline & Missed & 1 & $0.2 \%$ \\
\hline & Total & 465 & $100 \%$ \\
\hline \multirow{3}{*}{ Current Job Position } & $\begin{array}{l}\text { First line nurse manag- } \\
\text { ers }\end{array}$ & 105 & $22.58 \%$ \\
\hline & Staff Nurse & 360 & $77.4 \%$ \\
\hline & Total & 465 & $100 \%$ \\
\hline \multirow{5}{*}{ Current Work Area } & Critical Care Unit & 151 & $32.5 \%$ \\
\hline & Emergency Department & 40 & $8.6 \%$ \\
\hline & General Ward & 182 & $39.1 \%$ \\
\hline & Others & 92 & $19.8 \%$ \\
\hline & Total & 465 & $100 \%$ \\
\hline \multirow{5}{*}{ Experience (yrs.) } & $<5$ yrs. & 60 & $12.9 \%$ \\
\hline & $5-10$ yrs. & 215 & $46.2 \%$ \\
\hline & $10-20$ yrs. & 150 & $32.3 \%$ \\
\hline & $>20 y r s$ & 40 & $8.6 \%$ \\
\hline & Total & 465 & $100 \%$ \\
\hline
\end{tabular}

ii). Nursing perception to nursing work environment

Table 2: Nurse Participation in Hospital Affairs ( $\mathrm{N}=465)$

\begin{tabular}{lll}
\hline $\begin{array}{l}\mathrm{N} \\
\text { o. }\end{array}$ & Nurse participation in hospital affaires & $\begin{array}{l}\text { Mean } \\
\pm \mathrm{SD}\end{array}$ \\
\hline 1 & Career development/clinical ladder opportunity. & $2.43 \pm$ \\
& Opportunity for staff nurses to participate in policy deci- & 0.89 \\
2 & $\begin{array}{l}2.7 \pm 0 \\
\text { sions. }\end{array}$ & .94 \\
3 & A nurse in senior management is highly visible and accessi- & $2.36 \pm$ \\
& ble to staff & 0.86 \\
4 & A chief nursing officer equal in power and authority to & $2.46 \pm$ \\
& other top-level hospital executives & 0.85 \\
5 & Opportunities for advancement. & $2.47 \pm$ \\
& Administration that listens and responds to employee con- & 0.87 \\
6 & cerns. & $2.79 \pm$ \\
& Staff nurses are involved in the internal governance of the & 2.02 \\
7 & hospital (e.g., practice and policy committees). & 0.93 \\
& Staff nurses have the opportunity to serve on hospital and & $2.4 \pm 0$ \\
8 & nursing committees. & .85 \\
& Nursing administrators consult with staff on daily problems & $2.64 \pm$ \\
9 & and procedures & 0.99 \\
& & $2.55 \pm$ \\
Total & .69
\end{tabular}

\section{$* \mathrm{P} \leq 0.05$}

The above table illustrates that the nurses perceived moderately to nurse participation in hospital affairs.

Table 3: Nursing Foundation for Quality of Care $(\mathrm{N}=465)$

\begin{tabular}{lll}
\hline $\begin{array}{l}\mathrm{N} \\
\mathrm{o}\end{array}$ & Nursing Foundation for Quality of care & $\begin{array}{l}\text { Mea } \\
\mathrm{n} \pm \mathrm{S}\end{array}$ \\
$\mathrm{D}$
\end{tabular}




\begin{tabular}{lll}
\hline & & \pm 0.8 \\
& & 4 \\
5 & An active quality assurance program & 2.54 \\
& & \pm 0.9 \\
6 & A preceptor program for newly hired RNs & 3 \\
& & 2.04 \\
7 & Nursing care is based on a nursing, rather than a medical, & \pm 0.9 \\
& model. & 2.31 \\
& & \pm 0.8 \\
8 & Written, up-to-date nursing care plans for all patients. & 2 \\
& & 2.11 \\
9 & Patient care assignments that foster continuity of care, i.e., & \pm 0.9 \\
& the same nurse cares for the patient from one day to the next. & 2.36 \\
& & \pm 0.9 \\
1 & Use of nursing diagnoses. & 2.04 \\
0 & & \pm 0.8 \\
& & 9 \\
& Total & 2.22 \\
& & \pm 0.6 \\
\hline $\mathrm{P} \leq 0.05$ & 8 \\
\hline
\end{tabular}

The above table illustrates that the nurses perceived highly to the nursing foundation for quality of care.

Table 4: Nurse Manager Ability, Leadership, and Support of Nurses $(\mathrm{N}=465)$

\begin{tabular}{lll}
\hline $\begin{array}{l}\mathrm{N} \\
\mathrm{o}\end{array}$ & Nurse Manager Ability, Leadership, and support of nurses & $\begin{array}{l}\text { Mean } \\
\pm \mathrm{SD}\end{array}$ \\
\hline 1 & A supervisory staff that is supportive of the nurses. & $2.31 \pm$ \\
& Supervisors use mistakes as learning opportunities, not & 0.91 \\
$2.59 \pm$ \\
& criticism. & 0.91 \\
3 & A nurse manager who is a good manager and leader. & $2.43 \pm$ \\
& & 1.01 \\
4 & Praise and recognition for a job well done. & $2.57 \pm$ \\
& A nurse manager who backs up the nursing staff in decision & 1.01 \\
5 & making, even if the conflict is with a physician. & $2.51 \pm$ \\
& \multirow{2}{*}{ Total } & 0.97 \\
& & $2.48 \pm$ \\
\hline $\mathrm{P}<0.05$ & .76 \\
\hline
\end{tabular}

The above table illustrates that the nurses perceived moderately to nurse manager ability, leadership, and support of nurses.

\begin{tabular}{lll}
\multicolumn{3}{c}{ Table 5: Staffing and Resource Adequacy (N=465) } \\
\hline $\mathrm{N}$ & \multirow{2}{*}{ Staffing And Resource Adequacy } & Mean \pm \\
$\mathrm{o}$ & & $\mathrm{SD}$ \\
\hline 1 & Adequate support services allow me to spend time with & $2.41 \pm 1$ \\
& my patients. & $2.55 \pm 0$ \\
2 & Enough time and opportunity to discuss patient care prob- & .93 \\
& lems with other nurses & $2.9 \pm 1$. \\
3 & Enough registered nurses to provide quality patient care. & 17 \\
& & $3.09 \pm 1$ \\
4 & Enough staff to get the work done & .18 \\
& & $2.73 \pm$. \\
& Total & 83 \\
\hline
\end{tabular}

The above table illustrates that the nurses perceived moderately to staffing and resource adequacy

\begin{tabular}{lll}
\multicolumn{3}{c}{ Table 6: Collegial Nurse-Physician Relations (N=465) } \\
\hline $\mathrm{N}$ & Collegial Nurse-Physician Relations & Mean $\pm \mathrm{S}$ \\
$\mathrm{o}$ & & $\mathrm{D}$ \\
\hline 1 & Physicians and nurses have good working relationships. & $2.15 \pm 0.8$ \\
& & 6 \\
2 & A lot of teamwork between nurses and physicians. & $2.32 \pm 0.8$ \\
& Collaboration (joint practice) between nurses and phy- & $2.37 \pm 0.8$ \\
3 & sicians. & 2 \\
& Total & $2.27 \pm .7$ \\
\hline
\end{tabular}

The above table illustrates that the nurses perceived highly to Collegial Nurse-Physician Relations.

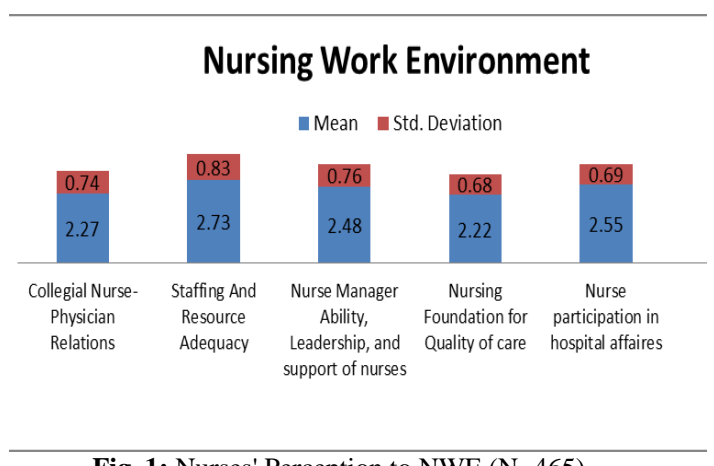

Fig. 1: Nurses' Perception to NWE (N=465).

The above figure illustrates the five categories/subscale of nursing work environment; the first subscale is nurse participation in hospital affairs, the mean score was 2.55. The second subscale is nursing foundations for quality of care with a mean score of 2.2. The third subscale is nurse manager ability, leadership, and support of nurses with a mean score of 2.48. The highest mean score among the five categories was staffing and resources adequacy with a mean score of 2.73 . The fifth subscale is collegial nursephysician relations with a mean score of 2.27 .

iii). Association between nurses' characteristics and their perception of the nursing work environment

Table 7: Nurses' Perception of Work Environment as Distributed by Their Age Group

\begin{tabular}{|c|c|c|c|c|c|c|c|}
\hline \multirow{2}{*}{$\begin{array}{l}\text { Nursing } \\
\text { works } \\
\text { envi- } \\
\text { ron- } \\
\text { ment } \\
\end{array}$} & \multicolumn{5}{|c|}{ Age $(\mathrm{X} \pm \mathrm{SD})$} & \multirow[b]{2}{*}{$\begin{array}{l}\text { Test } \\
\text { One } \\
\text { Way } \\
\text { ANO } \\
\text { VA } \\
\end{array}$} & \multirow[b]{2}{*}{$\begin{array}{l}* \mathrm{P} \\
\text { val- } \\
\text { ue }\end{array}$} \\
\hline & $\begin{array}{l}20 \geq 30 \\
\text { yrs. } \\
n=166\end{array}$ & $\begin{array}{l}30 \geq 40 \\
\text { yrs. } \\
n=189\end{array}$ & $\begin{array}{l}40 \geq 50 \\
\text { yrs. } \\
n=83\end{array}$ & $\begin{array}{l}50+ \\
\text { yrs. } \\
n=27\end{array}$ & $\begin{array}{l}\text { Total } \\
\mathrm{n}=465\end{array}$ & & \\
\hline $\begin{array}{l}\text { Nurse } \\
\text { partici- } \\
\text { pation } \\
\text { in hos- } \\
\text { pital } \\
\text { affaires }\end{array}$ & $\begin{array}{l}2.63 \pm \\
0.72\end{array}$ & $\begin{array}{l}2.57 \pm \\
0.64\end{array}$ & $\begin{array}{l}2.46 \pm \\
0.73\end{array}$ & $\begin{array}{l}2.24 \pm \\
0.57\end{array}$ & $\begin{array}{l}2.55 \pm \\
0.69\end{array}$ & 3.08 & 0.02 \\
\hline $\begin{array}{l}\text { Nursing } \\
\text { Foun- } \\
\text { dation } \\
\text { for }\end{array}$ & $\begin{array}{l}2.27 \pm \\
0.76\end{array}$ & $\begin{array}{l}2.28 \pm \\
0.6\end{array}$ & $\begin{array}{l}2.11 \pm \\
0.72\end{array}$ & $\begin{array}{l}1.83 \pm \\
0.5\end{array}$ & $\begin{array}{l}2.22 \pm \\
0.68\end{array}$ & 4.61 & 0.00 \\
\hline $\begin{array}{l}\text { Quality } \\
\text { of care } \\
\text { Nurse } \\
\text { Manag- } \\
\text { er Abil- } \\
\text { ity, }\end{array}$ & & & & & & & \\
\hline $\begin{array}{l}\text { Leader- } \\
\text { ship, } \\
\text { and } \\
\text { support } \\
\text { of } \\
\text { nurses }\end{array}$ & $\begin{array}{l}2.56 \pm \\
0.75\end{array}$ & $\begin{array}{l}2.50 \pm \\
0.73\end{array}$ & $\begin{array}{l}2.35 \pm \\
0.83\end{array}$ & $\begin{array}{l}2.20 \pm \\
0.67\end{array}$ & $\begin{array}{l}2.48 \pm \\
0.76\end{array}$ & 2.69 & 0.04 \\
\hline $\begin{array}{l}\text { Staffing } \\
\text { And }\end{array}$ & & & & & & & \\
\hline $\begin{array}{l}\text { Re- } \\
\text { source } \\
\text { Ade- } \\
\text { quacy }\end{array}$ & $\begin{array}{l}2.74 \pm \\
0.85\end{array}$ & $\begin{array}{l}2.79 \pm \\
0.8\end{array}$ & $\begin{array}{l}2.64 \pm \\
0.88\end{array}$ & $\begin{array}{l}2.55 \pm \\
0.71\end{array}$ & $\begin{array}{l}2.73 \pm \\
0.83\end{array}$ & 1.13 & 0.33 \\
\hline $\begin{array}{l}\text { Colle- } \\
\text { gial }\end{array}$ & & & & & & & \\
\hline $\begin{array}{l}\text { Nurse- } \\
\text { Physi- } \\
\text { cian } \\
\text { Rela- } \\
\text { tions }\end{array}$ & $\begin{array}{l}2.35 \pm \\
0.8\end{array}$ & $\begin{array}{l}2.30 \pm \\
0.67\end{array}$ & $\begin{array}{l}2.14 \pm \\
0.77\end{array}$ & $\begin{array}{l}2.02 \pm \\
0.58\end{array}$ & $\begin{array}{l}2.27 \pm \\
0.74\end{array}$ & 2.55 & 0.05 \\
\hline
\end{tabular}

The table above illustrates that there were significant differences between age groups in relation to nursing participation in hospital 
affairs; the lowest mean score 2.24 for $50+$ yrs. The group, while the highest mean score 2.63 were for the age group between $20 \geq 30$ yrs. The table also shows significance differences p-value 0.00 between the age groups in relation to the nursing foundation for quality of care; the lowest mean score 1.83 for $>50$ yrs. The group, while the highest mean score 2.28 were for the age group between 30-40 yrs. The table similarly illustrates significance differences p-value 0.04 between the age groups in relation to nurse manager ability, leadership, and support of nurses; the lowest mean score 2.2 for $>50$ yrs. The group, while the highest mean score 2.56 were for the age group between $20 \geq 30$ yrs.

There were no significance differences among the genders in this study in relation to their perception of nursing work environment except in nursing foundation for quality of care the table shows that the male group is perceived higher than female.

Table 8: Nurses' Perception for Work Environment as Distributed by Their Education Group

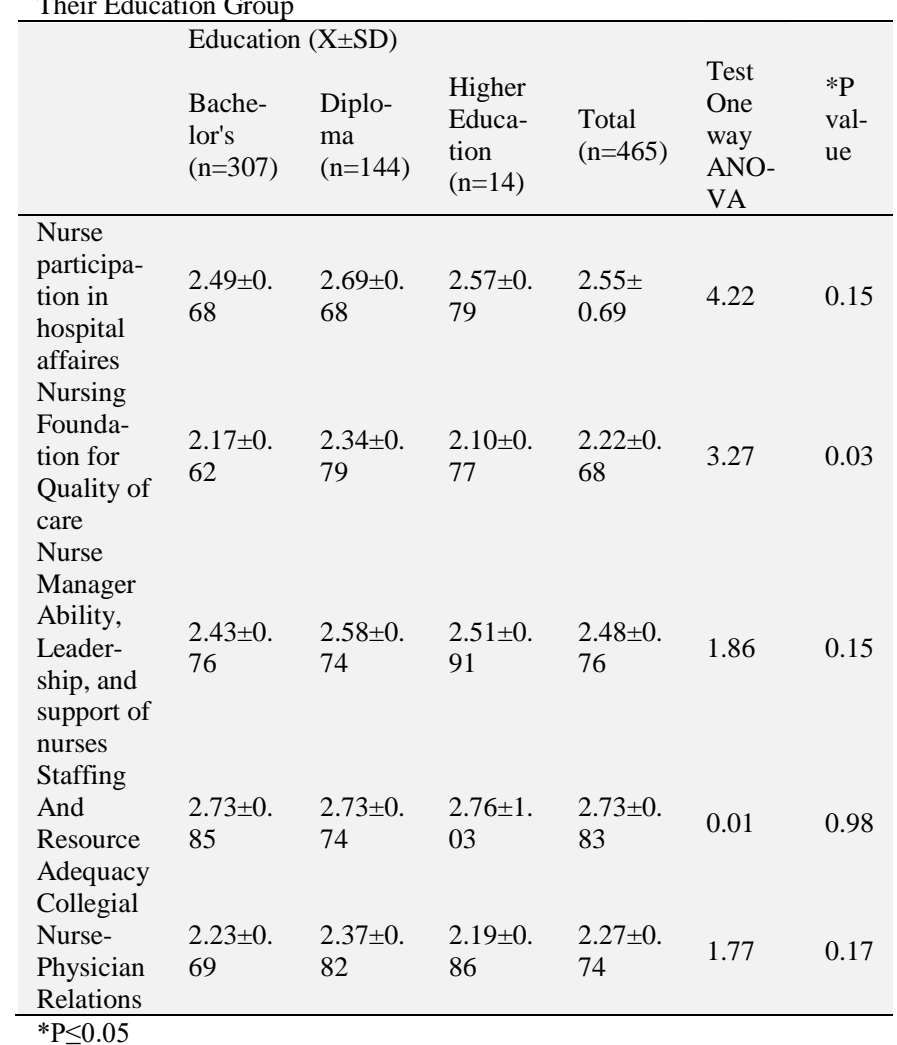

The above table illustrate that there were significant differences between groups of different educational levels in relation to nursing foundation for quality of care with p-value 0.03 . The highest mean score is 2.34 for diploma group, while the lowest mean score is 2.1 for higher education group.

Table 9: Nurses' Perception for Work Environment as Distributed by Their Certification Group

\begin{tabular}{|c|c|c|c|c|}
\hline \multirow{2}{*}{$\begin{array}{l}\text { Nursing work envi- } \\
\text { ronment }\end{array}$} & \multicolumn{2}{|c|}{ Certification $(\mathrm{X} \pm \mathrm{SD})$} & \multirow{2}{*}{$\begin{array}{l}\text { Test } \\
\text { (Independent } \\
\text { T-test) }\end{array}$} & \multirow{2}{*}{$\begin{array}{l}* \mathrm{P} \\
\text { value }\end{array}$} \\
\hline & $\begin{array}{l}\text { No } \\
(n=327)\end{array}$ & $\begin{array}{l}\text { Yes } \\
(n=137)\end{array}$ & & \\
\hline $\begin{array}{l}\text { Nurse participation } \\
\text { in hospital affaires }\end{array}$ & $2.61 \pm 0.67$ & $2.40 \pm 0.7$ & 3.06 & 0.00 \\
\hline $\begin{array}{l}\text { Nursing Foundation } \\
\text { for Quality of care }\end{array}$ & $2.28 \pm 0.69$ & $2.09 \pm 0.64$ & 2.68 & 0.00 \\
\hline Nurse Manager & $2.52 \pm 0.77$ & $2.38 \pm 0.73$ & 1.69 & \\
\hline $\begin{array}{l}\text { Ability, Leadership, } \\
\text { and support of } \\
\text { nurses }\end{array}$ & & & & 0.09 \\
\hline $\begin{array}{l}\text { Staffing And Re- } \\
\text { source Adequacy }\end{array}$ & $2.77 \pm 0.8$ & $2.62 \pm 0.87$ & 1.78 & 0.07 \\
\hline $\begin{array}{l}\text { Collegial Nurse- } \\
\text { Physician Relations }\end{array}$ & $2.31 \pm 0.76$ & $2.19 \pm 0.68$ & 1.58 & 0.11 \\
\hline
\end{tabular}

The above table illustrate that there were significance differences between the two groups in nursing participation in hospital affaires with p-value 0.00 ; the low mean score 2.4 for group who have special certification, while the mean score 2.61 for the group with no certification. Also, the table shows significance differences between the two groups with p-value 0.00 in relation to nursing foundation for quality of care; the low mean score 2.09 for group who have special certification while the mean score 2.28 for the group with no certification.

Table 10: Nurses' Perception for Work Environment as Distributed by Their Position Group

\begin{tabular}{|c|c|c|c|c|}
\hline $\begin{array}{l}\text { Nursing work } \\
\text { environment }\end{array}$ & $\begin{array}{l}\text { Position }(X \\
\text { first line } \\
\text { manager } \\
(n=105)\end{array}$ & $\begin{array}{l}\text { Staff nurs- } \\
\text { es }(n=360)\end{array}$ & $\begin{array}{l}\text { Test } \\
\text { (Independent T- } \\
\text { test) }\end{array}$ & $\begin{array}{l}* \mathrm{P} \\
\text { value }\end{array}$ \\
\hline $\begin{array}{l}\text { Nurse participa- } \\
\text { tion in hospital } \\
\text { affaires }\end{array}$ & $2.29 \pm 0.68$ & $2.63 \pm 067$ & -4.49 & 0.00 \\
\hline $\begin{array}{l}\text { Nursing Founda- } \\
\text { tion for Quality of } \\
\text { care }\end{array}$ & $2.10 \pm 0.98$ & $2.59 \pm 0.74$ & $-5.97-$ & 0.00 \\
\hline Nurse Manager & $2.02 \pm 0.67$ & $2.28 \pm 0.68$ & $-3.53-$ & \\
\hline $\begin{array}{l}\text { Ability, Leader- } \\
\text { ship, and support } \\
\text { of nurses }\end{array}$ & & & & 0.00 \\
\hline Staffing & $2.59 \pm 0.83$ & $2.27 \pm 0.82$ & $-1.97-$ & \\
\hline $\begin{array}{l}\text { Resource Ade- } \\
\text { quacy }\end{array}$ & & & & 0.04 \\
\hline $\begin{array}{l}\text { Collegial } \\
\text { Physician } \\
\text { tions }\end{array}$ & $2.06 \pm 0.73$ & $2.33 \pm 0.73$ & $-3.29-$ & 0.00 \\
\hline
\end{tabular}

The above table illustrates that there was significant differences between different levels of the position of a participant in relation to all categories of the nursing work environment.

The p-value 0 between the groups in relation to nursing participation in hospital affairs; the highest mean score 2.63 for staff nurse, while the lowest mean score 2.02 for head nurse. Also, there was significance differences with p-value 0.001 between the groups in relation to the nursing foundation for quality of care; the highest mean score 2.32 for others, while the lowest mean score 1.78 for head nurses. The significance differences with p-value 0 between the groups in relation to nurse manager ability, leadership and support of nurses; the highest mean score 2.59 for staff nurses, while the lowest mean score 1.78 for head nurses. Also, there was significance differences with p-value 0.046 between the groups in relation to staffing and resource adequacy; the highest mean score 2.77 for head nurses, while the lowest mean score 2.32 for head nurses. The tables illustrate furthermore the significance differences between the groups with p-value 0.004 in relation to collegial nurse-physician relations; the highest mean score 2.41 for others, while the lowest mean score 1.9 for head nurses.

Table 11: Nurses' Perception of the Work Environment as Distributed by Their Unit/Area Group

\begin{tabular}{|c|c|c|c|c|c|c|c|}
\hline \multirow[b]{2}{*}{$\begin{array}{l}\text { Nursing } \\
\text { works } \\
\text { envi- } \\
\text { ronment }\end{array}$} & \multicolumn{4}{|c|}{ Unit/Area $(\mathrm{X} \pm \mathrm{SD})$} & \multicolumn{3}{|c|}{ Test } \\
\hline & $\begin{array}{l}\text { Criti- } \\
\text { cal } \\
(\mathrm{n}=15 \\
1)\end{array}$ & $\begin{array}{l}\text { ER } \\
(n=40 \\
)\end{array}$ & $\begin{array}{l}\text { Gen- } \\
\text { eral. } \\
(n=18 \\
2)\end{array}$ & $\begin{array}{l}\text { Other } \\
(n=92 \\
)\end{array}$ & $\begin{array}{l}\text { Total } \\
(\mathrm{n}=46 \\
5)\end{array}$ & $\begin{array}{l}\text { One } \\
\text { way } \\
\text { ANO } \\
\text { VA }\end{array}$ & $\begin{array}{l}* \mathrm{P} \\
\text { val } \\
\text { ue }\end{array}$ \\
\hline $\begin{array}{l}\text { Nurse } \\
\text { partici- } \\
\text { pation } \\
\text { in hos- } \\
\text { pital } \\
\text { affaires } \\
\text { Nursing }\end{array}$ & $\begin{array}{l}2.60 \pm \\
0.73\end{array}$ & $\begin{array}{l}2.59 \pm \\
0.68\end{array}$ & $\begin{array}{l}2.51 \pm \\
0.67\end{array}$ & $\begin{array}{l}2.52 \pm \\
0.66\end{array}$ & $\begin{array}{l}2.55 \pm \\
0.69\end{array}$ & 0.59 & $\begin{array}{l}0.6 \\
2\end{array}$ \\
\hline $\begin{array}{l}\text { Founda- } \\
\text { tion for } \\
\text { Quality } \\
\text { of care }\end{array}$ & $\begin{array}{l}2.32 \pm \\
0.78\end{array}$ & $\begin{array}{l}2.27 \pm \\
0.66\end{array}$ & $\begin{array}{l}2.18 \pm \\
0.63\end{array}$ & $\begin{array}{l}2.12 \pm \\
0.61\end{array}$ & $\begin{array}{l}2.22 \pm \\
0.68\end{array}$ & 2.00 & $\begin{array}{l}0.1 \\
1\end{array}$ \\
\hline $\begin{array}{l}\text { Nurse } \\
\text { Manag- } \\
\text { er Abil- }\end{array}$ & $\begin{array}{l}2.57 \pm \\
0.75\end{array}$ & $\begin{array}{l}2.39 \pm \\
0.80\end{array}$ & $\begin{array}{l}2.47 \pm \\
0.79\end{array}$ & $\begin{array}{l}2.39 \pm \\
0.70\end{array}$ & $\begin{array}{l}2.48 \pm \\
0.76\end{array}$ & 1.33 & $\begin{array}{l}0.2 \\
6\end{array}$ \\
\hline
\end{tabular}




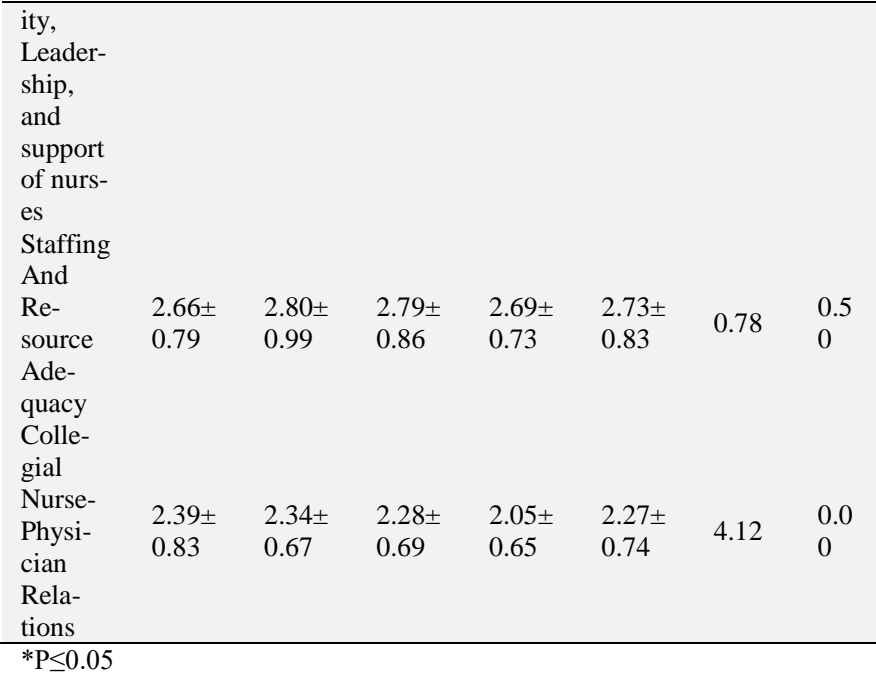

The above table illustrates the significance differences between the groups from different unit/area with p-value 0.007; the highest mean score 2.39 for critical care units, while the lowest mean score 2.05 for others. There was no significance between the groups in relation to other categories of the nursing work environment.

Table 12: Nurses' Perception of Work Environment as Distributed by Their Experience Group

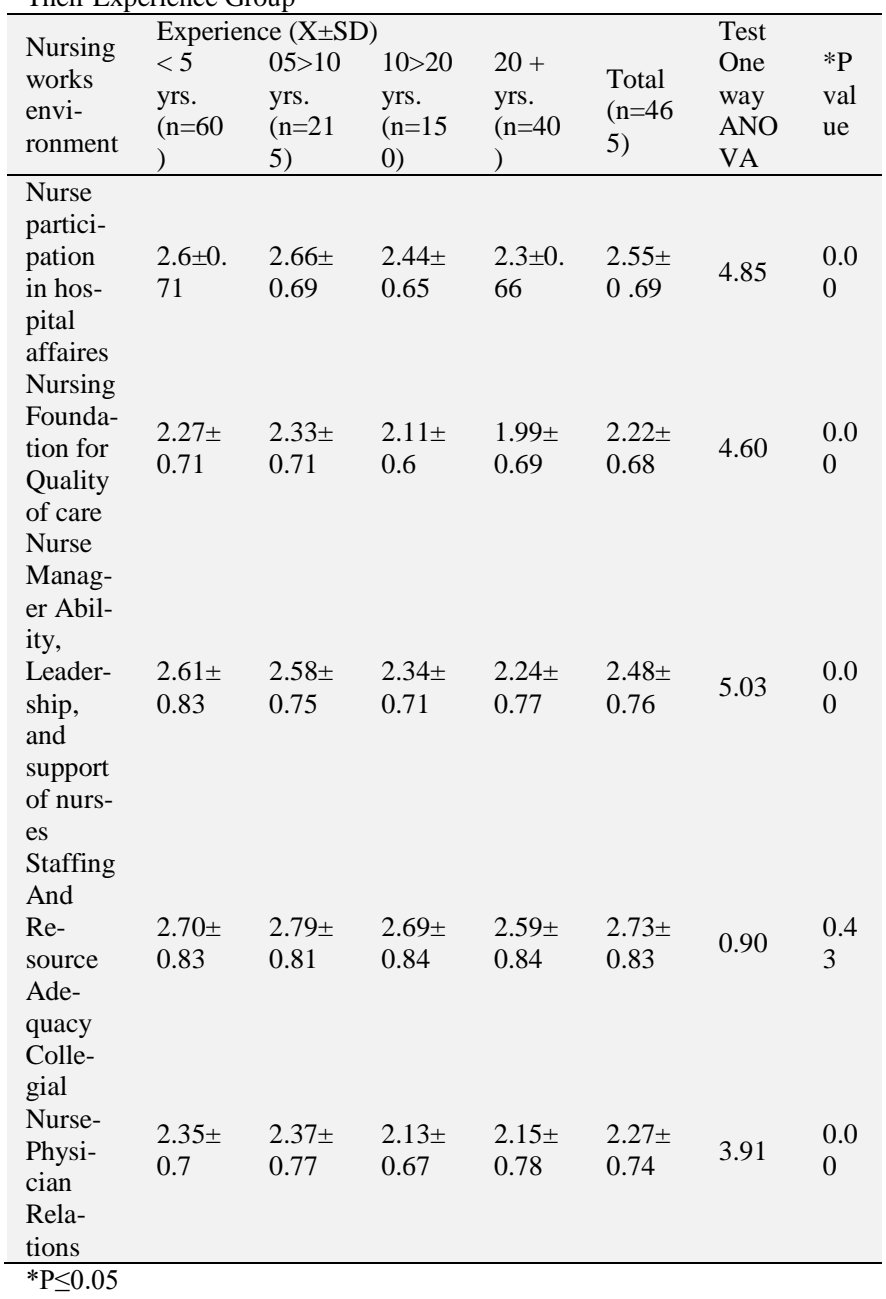

The above table illustrates that there were significant differences between participant experience in relation to all categories of nursing work environment except staffing and resource adequacy there was no significance differences. The p-value 0.002 between the groups in relation to nursing participation in hospital affairs; the highest mean score 2.66 for participants with $05-10$ yrs. experi- ence, while the lowest mean score 2.3 for participants who have more than 20 yrs. experience. Also, there was significance with pvalue 0.003 between the groups in relation to the nursing foundation for quality of care; the highest mean score 2.33 for a group of 5-10 yrs. experience, while the lowest mean score 1.99 for participants who have more than 20 yrs. experience. The significance differences with p-value 0.002 between the groups in relation to nurse manager ability, leadership, and support of nurses; the highest mean score 2.61 for participants who have less than 5 yrs. experience, while the lowest mean score 2.24 for participants who have more than $20 \mathrm{yrs}$. experience. The tables illustrate also the significance differences between the groups of experience with pvalue 0.009 in relation to collegial nurse-physician relations; the highest mean score 2.37 for participants with 05-10 yrs. experience, while the lowest mean score 2.13 for participants with experience of 10-20 yrs.

\section{Discussion}

The result of this study addressed the nursing work environment as five categories; Nurse Participation in hospital affairs, the nurses perceived "moderate" to participate in hospital affairs. There were a significance differences in this study among the participants in this category in relation to age nurses age between $20 \geq 30$ perceived less participate in hospital affairs than others age groups Nurses who have special certification perceived less participation in hospital affairs than those nurses who don't have special certification. In this study staff nurses perceived less participation in hospital affairs than first line managers. These findings are consistent a study conducted by Anzai et al., 2014, that showed nurse managers were more likely to rate participation in hospital affairs higher compared to staff nurses.

The nurses who had over $5>10$-year experiences perceived less participation in hospital affairs. The second category of nursing work environment was Nursing Foundation for Quality of care, the nurses reported high perception towards this category. Kieft, et al, 2014, conducted a qualitative study to understand the perspective of nurses of how the nursing work environment is related to positive patient experiences. The nurses in this study stated that to improve patient experiences, the nurses should have autonomy over their own practice; the quality of patient care is greater when the foundations for quality of care are present in their present job. In the USA, the nurses demonstrated that the accessibility of educational chances was related to nurses' perceptions of the quality of care (Ulrich et al., 2006). Kelly, Kutney-Lee, Lake, and Aiken, 2013 reported that the nurses rate highest score in foundations for quality of care compare to other categories. The current study showed that there were significant differences between age groups in relation to the nursing foundation for quality of care.

Nurses age between $20 \geq 30$ perceived less compare to other age groups especially those nurses over the age of 50, the male nurses agree less than female in relation to the nursing foundation for quality of care, the nurses who have diploma qualification perceived less than other qualified nurses, the nurses with special certification perceived more in relation to the nurses who don't have special certification, the staff nurses group perceived less than first line managers in relation to the nursing foundation for quality of care, the nurses who had $5>10$ years experiences perceived less in the nursing foundation for quality of care compare to those with over 20 years' experience. In contrast with a study conducted by Anzai et al., 2014, found that nurses with less than five years' experience were the strongest predictors of ability to provide quality nursing care. Kieft et al., 2014, the study reported that nurses' experiences were important for patients because it is related to the quality of care.

Participants of Kieft et al., 2014, study believed that nursing experience was also of influence. According to them, a junior nurse has too little experience to respond creatively to sometimes complex care situations. However, according to participants, junior and senior nurses can learn from each other: they should work as a 
team and collectively pursue their common objectives. In their view, the experience is gained through practice. According to participants, this can be characterized as 'expertise'.

Boev, 2011, study showed that the foundations for quality care subscale received the highest scores, suggesting that these nurses are satisfied with the quality assurance processes on their units. The third category of nursing work environment was Nurse Manager Ability, Leadership, and support of nurses, the nurses reported a moderate agreement in relation to this category. According to Aiken et al., 2008; Leiter \& Laschinger, 2006, reported that the strong nursing leadership in the practice area has been known in general nursing research as a significant predictor of better outcomes for nurses and patients.

The current study showed that there were significant differences between nurses' age groups, the age $20 \geq 30$ years had less perception than other groups, staff nurses perceived lower than first-line nurse managers. These findings are consistent with study conducted by Brady Germain \& Cummings, 2010; Anthony, Standing, Glick, Duffy, Modic, and Dumpe, 2005, that examined the role of nurse managers in the work environment, and showed that nurse manager keeps a pivotal role in making and supporting a healthy work environment for nurses. Some of the major managers' duties essential for nurses motivation and performance development are Human resources issues, such as nurses' attraction and retention, collaboration promotion, conflict management and resolution and finally confirming of acceptable resources.

The current study showed that the nurses with less than 5 years of experiences had lower perception compare to those with over 5 years of experiences. The fourth category of nursing work environment was Staffing and Resource Adequacy, the nurse's perceived moderate perception related to this category. In a study conducted by Kalisch \&Lee, 2011, the nurses were more satisfied when staffing overall was apparent to be adequate. In Finland and the Netherlands there was a significant relationship between nurse staffing and adverse patient outcomes in hospital settings (Hinno et al., 2012).

A meta-analysis of 28 studies (Kane et al, 2007) found a high degree of stability in the relationships between staffing and skill mix, nurse outcomes i.e. Job satisfaction and burnout, and patient outcomes i.e. Mortality and adverse events. Nursing shortages compromise the safety and quality of patient care thus it is essential that organizational address the factors of nurse and patient outcomes (Anzai et al, 2014). The current study showed that there were no associations between nurses' characteristics and staffing and resource adequacy except the position. The first-line nurse managers reported lower perception than staff nurses.

These findings are consistent with a study conducted by Anzai et al., 2014, that showed Nurse Managers were more likely to rate each aspect of the practice environment higher compared to staff nurses, with the exception of staffing and resources. A study by Boev, 2011, showed that staffing and resource adequacy subscale received the lowest score, suggesting that dissatisfaction with workload was an important issue for these units. The fifth category of nursing work environment was Collegial Nurse-Physician Relations, the nurses' perceived higher agreement toward this category.

Roche \& Duffield, 2010; Pullon, 2008; Weaver, 2012 conducted similar studies and found that nurses perceived significantly stronger relationships with doctors. They identified three elements that should be demonstrated in the relationship between nurses, doctors, and other health professionals in order to function effectively in delivering health-care, these elements are; respect, trust, and competence. Study of Hino et al., 2009 reported that RNs perceived the nurse-physician relationship as relatively high. On the other hand, professional relationships between doctors and nurses have often remained problematic (Pullon, 2008). In the United States, a study of general nurses established strong relations between collegial relationships, stress, and nurses' job satisfaction (Manojlovich, 2005). In Australian the nurse-doctor relationship in mental health has been linked to the effect nurses have in decisions about patient treatment (Elsom et al, 2007).
In contrast, multiple types of research conducted by Duffield et al, 2009; Roche et al., 2010, identified an association between nursedoctor relationships, nurses' job satisfaction, and reported the experience of threats of violence, these study similar to study conducted by Chebor et al, 2014, their findings was a poor working relationship between nurses and physicians.

In this study, there was significance association between collegial nurse-physician relations and age; the nurses' $20 \geq 30$ years reported lower agreement compare to those over 30 years of age. Staff nurses had less perception than the first line managers in relation to the nurse-physician relationship. Critical care nurses reported lower agreement on the nurse-physician relationship than nurses who are not working in the critical area. The nurses with $5>10$ years of experiences perceived less than those the age of 10 years and above in relation to the nurse-physician relationship.

\section{Conclusion}

Perception of work environment characteristics was moderately high, the nursing foundation for quality of care as well as the nurse-physician relationship was considered the highest aspect of the work environment while staffing and resources adequacy was the lowest important aspect. The interesting finding in this study that the staff nurses had higher perception than nurse managers in relation to staffing and resources adequacy.

Several previous studies findings supported our current study, where some other study's findings differ in certain aspects of our study. The findings from this study provided empirical support for the future theoretical structure of nursing work environment.

\section{Recommendation}

This study is useful in directing attention to the influence of work environment on nurses' perception of their control over nursing practice. The current study highlighted the recommendation that will be beneficial to nursing administration, practice, education and research. Nurse executives need to engage, guide and teach nurse managers to empower their staff by create a healthy work environment. The findings of this study need to be measured first at the hospital, then at the national level, later they could be used for benchmarking at heights to the international setting. This approach can be especially useful in understanding how to design work in ways that create safer care environments for patients and healthier work environments for nurses. Magnet Hospital standards could be a practical intervention to improve staff to have control on their practice. Nursing administrator need to provide healthy work environment to and encourage the nurses' managers to involve their staff in decision making activities, to be more confident and aware to shape the departmental policy.

\section{Acknowledgement}

Thanks to the participants in the survey Ms. Darna and Mr. Ceser who facilitate the data entry. Appreciative to the king fahad medical city for providing the opportunity to conduct this study. And providing research center services that were effective and funded the study. Also thanks for Mr. Tariq and Dr. Nassr for helping in statistical analysis.

\section{References}

[1] Aboshaiqah, A. E. (2015). Nursing work environment in Saudi Arabia. Journal of nursing management, 23(4), 510-520. https://doi.org/10.1111/jonm.12164.

[2] Aiken, L. H., Clarke, S. P., Sloane, D. M., Lake, E. T., \& Cheney, T. (2008). Effects of hospital care environment on patient mortality and nurse outcomes. The Journal of nursing administration, 38(5), 223. https://doi.org/10.1097/01.NNA.0000312773.42352.d7. 
[3] Aiken, L. H., \& Patrician, P. A. (2000). Measuring organizational traits of hospitals: the Revised Nursing Work Index. Nursing research, 49(3), 146-153. $\quad$ https://doi.org/10.1097/00006199200005000-00006.

[4] American Nurses Association, ANA 2011 Health and Safety Survey. Nursing world. Retrieved from: http://www.nursingworld.org/MainMenuCategories/WorkplaceSafe ty/Healthy-Work-Environment/Work-Environment/2011-

HealthSafetySurvey.html.

[5] American Association of Colleges of Nursing. 2008. Nursing shortage fact sheet. Unpublished manuscript. Retrieved from: http://www.aacn.nche.edu/media-relations/NrsgShortageFS.pdf (accessed 21.05.2010)

[6] Anthony, M. K., Standing, T. S., Glick, J., Duffy, M., Paschall, F., Sauer, M. R., \& Dumpe, M. L. (2005).

[7] Leadership and nurse retention: the pivotal role of nurse managers. Journal of Nursing Administration, 35(3), 146-155.

[8] Anzai, E., Douglas, C., \& Bonner, A. (2014). Nursing practice environment, quality of care, and morale of hospital nurses in Japan. Nursing \& health sciences, 16(2), 171-178. https://doi.org/10.1111/nhs.12081.

[9] Arford, P. H., \& Zone-Smith, L. (2005). Organizational commitment to professional practice models. Journal of nursing administration, 35(10), 467-472. https://doi.org/10.1097/00005110200510000-00008.

[10] Baernholdt, M., \& Mark, B. A. (2009). The nurse work environment, job satisfaction and turnover rates in rural and urban nursing units. Journal of nursing management, 17(8), 994-1001. https://doi.org/10.1111/j.1365-2834.2009.01027.x.

[11] Boev, C. A. (2011). The Relationship between Nurses' Perception of Work Environment and Nurse-sensitive Patient Outcomes in Adult Critical Care (Doctoral dissertation, University of Rochester).

[12] BRADY GERMAIN, P. A. M. E. L. A., \& Cummings, G. G (2010). The influence of nursing leadership on nurse performance: a systematic literature review. Journal of Nursing Management, 18(4), 425-439. https://doi.org/10.1111/j.1365-2834.2010.01100.x.

[13] British Columbia Nurses Union Statement on Nurse Autonomy (2011). Retrieved from: https://www.bcnu.org/AboutBcnu/Documents/position-statementnurse-autonomy.pdf

[14] Brunoro, C. S. (2007). Clinical nurse perceptions of who governs the professional environment including control over practice in provincial hospitals in Saskatchewan (Doctoral dissertation, University of Saskatchewan, Saskatoon).

[15] Budge, C., Carryer, J., \& Wood, S. (2003). Health correlates of autonomy, control and professional relationships in the nursing work environment. Journal of advanced nursing, 42(3), 260-268. https://doi.org/10.1046/j.1365-2648.2003.02615.x.

[16] Chebor, A., Simiyu, K., Tarus, T., Mangeni, J., \& Obel, M. Nurses Perception of their Work Environment at a Referral Hospital in Western Kenya.

[17] Cohen, J., Stuenkel, D., \& Nguyen, Q. (2009). Providing a healthy work environment for nurses: the influence on retention. Journal of Nursing Care Quality, 24(4), 308-315. https://doi.org/10.1097/NCQ.0b013e3181a4699a.

[18] Cramer, E., Staggs, V., \& Dunton, N. (2014). Improving the nursing work environment. American Nurse Today, 9, 55-57.

[19] DiMeglio, K., Padula, C., Piatek, C., Korber, S., Barrett, A., Ducharme, M., \& Corry, K. (2005). Group Cohesion and Nurse Satisfaction: Examination of a Team-Building Approach. Journal of Nursing Administration, 35(3), 110-120. https://doi.org/10.1097/00005110-200503000-00003.

[20] Duffield, C., Roche, M., O’Brien-Pallas, L., Catling-Paull, C., \& King, M. (2009). Staff satisfaction and retention and the role of the nursing unit manager. Collegian, 16(1), 11-17. https://doi.org/10.1016/j.colegn.2008.12.004.

[21] Dall, T. M., Chen, Y. J., Seifert, R. F., Maddox, P. J., \& Hogan, P. F. (2009). The economic value of professional nursing. Medical care, (1),

97-104. https://doi.org/10.1097/MLR.0b013e3181844da8

[22] Elsom, S., Happell, B., \& Manias, E. (2007). Exploring the expanded practice roles of community mental health nurses. Issues in Mental Health Nursing, 28(4), 413-429. https://doi.org/10.1080/01612840600943739.

[23] Erickson, J. I., Duffy, M. E., Gibbons, M. P., Fitzmaurice, J., Ditomassi, M., \& Jones, D. (2004).

[24] Development and psychometric evaluation of the professional practice environment (PPE) scale. Journal of Nursing Scholarship, 36(3), 279-285. https://doi.org/10.1111/j.1547-5069.2004.04050.x.
[25] Fagin, L., \& Garelick, A. (2004). The doctor-nurse relationship. Advances in Psychiatric Treatment, 10(4), 277-286. https://doi.org/10.1192/apt.10.4.277.

[26] Force, M. V. (2005). The relationship between effective nurse managers and nursing retention. Journal of nursing administration, 35(7-8), 336-341. https://doi.org/10.1097/00005110-20050700000005 .

[27] Hall, L. M., Doran, D., Baker, G. R., Pink, G. H., Sidani, S., O’Brien-Pallas, L., \& Donner, G. J. (2003).

[28] Nurse staffing models as predictors of patient outcomes. Medical care, 41(9), 1096-1109. https://doi.org/10.1097/01.MLR.0000084180.07121.2B.

[29] Hinno, S., Partanen, P., VEHVILÄINEN-JULKUNEN, K. A. T. R. I., \& Aaviksoo, A. (2009). Nurses' perceptions of the organizational attributes of their practice environment in acute care hospitals Journal of nursing management, 17(8), 965-974. https://doi.org/10.1111/j.1365-2834.2009.01008.x.

[30] Hinno, S., Partanen, P., \& Vehviläinen-Julkunen, K. (2012). The professional nursing practice environment and nurse-reported job outcomes in two European countries: a survey of nurses in Finland and the Netherlands. Scandinavian journal of caring sciences, 26(1) 133-143. https://doi.org/10.1111/j.1471-6712.2011.00920.x

[31] Hinshaw, A. S. (2002). Building magnetism into health organizations. Magnet hospitals revisited: attraction and retention of professional nurses. Washington, DC: American Nurses Publishing, 83-102.

[32] Institute of Medicine. (2004). Keeping patients safe: Transforming the work environment of nurses.

[33] Washington, DC: National Academy Press. Retrieved from: http://www.nap.edu/download.php?record_id=10851

[34] Kalisch, B. J., Curley, M., \& Stefanov, S. (2007). An intervention to enhance nursing staff teamwork and engagement. Journal of Nursing Administration, 37(2), 77-84. https://doi.org/10.1097/00005110-200702000-00010.

[35] Kalisch, B. J., \& Lee, K. H. (2011). Nurse Staffing Levels and Teamwork: A Cross-Sectional Study of

[36] Patient Care Units in Acute Care Hospitals. Journal of nursing scholarship, 43(1), 82-88. https://doi.org/10.1111/j.15475069.2010.01375.x.

[37] Kane, R. L., Shamliyan, T. A., Mueller, C., Duval, S., \& Wilt, T. J. (2007). The association of registered nurse staffing levels and patient outcomes: systematic review and meta-analysis. Medical care, 45(12), https://doi.org/10.1097/MLR.0b013e3181468ca3

[38] Kelly, D., Kutney-Lee, A., Lake, E. T., \& Aiken, L. H. (2013). The critical care work environment and nurse-reported health careassociated infections. American Journal of Critical Care, 22(6), 482-488. https://doi.org/10.4037/ajcc2013298.

[39] Kieft, R. A., de Brouwer, B. B., Francke, A. L., \& Delnoij, D. M. (2014). How nurses and their work environment affect patient experiences of the quality of care: a qualitative study. BMC health ser vices research, 14(1), 249. https://doi.org/10.1186/1472-6963-14249 .

[40] Klopper, H. C., Coetzee, S. K., Pretorius, R., \& Bester, P. (2012). Practice environment, job satisfaction and burnout of critical care nurses in South Africa. Journal of Nursing Management, 20(5), 685-695. https://doi.org/10.1111/j.1365-2834.2011.01350.x.

[41] Kramer, M., \& Hafner, L. P. (1989). Shared values: impact on staff nurse job satisfaction and perceived productivity. Nursing research 38(3), 172-177. $\quad$ https://doi.org/10.1097/00006199-198905000$\underline{00019}$

[42] Kramer, M., Schmalenberg, C., \& Maguire, P. (2004). Essentials of a magnetic work environment part 4. Nursing2015, 34(9), 44-48. https://doi.org/10.1097/00152193-200409000-00039.

[43] Lake, E. T. (2002). Development of the practice environment scale of the nursing work indext+. Research in nursing \& health, 25(3), 176-188. https://doi.org/10.1002/nur.10032.

[44] Lankshear, A. J., Sheldon, T. A., \& Maynard, A. (2005). Nurse staffing and healthcare outcomes: a systematic review of the international research evidence. Advances in Nursing Science, 28(2), 163-174. https://doi.org/10.1097/00012272-200504000-00008.

[45] Laschinger, H. K. S., \& Leiter, M. P. (2006). The impact of nursing work environments on patient safety outcomes: The mediating role of burnout engagement. Journal of Nursing Administration, 36(5), 259-267. https://doi.org/10.1097/00005110-200605000-00019.

[46] Laschinger, H. K. S., Finegan, J. E., Shamian, J., \& Wilk, P. (2004) A longitudinal analysis of the impact of workplace empowerment on work satisfaction. Journal of Organizational Behavior, 25(4), 527-545. https://doi.org/10.1002/job.256. 
[47] Laschinger, H. K. S. (2008). Effect of empowerment on professional practice environments, work satisfaction, and patient care quality: Further testing the nursing worklife model. Journal of nursing care quality, 23(4), 322-330. https://doi.org/10.1097/01.NCQ.0000318028.67910.6b.

[48] Laschinger, H. K. S., \& Havens, D. S. (1996). Staff nurse work empowerment and perceived control over nursing practice: conditions for work effectiveness. Journal of Nursing Administration, 26(9), 27-35. https://doi.org/10.1097/00005110-199609000-00007.

[49] Laschinger, H. K. S., Finegan, J., \& Wilk, P. (2009). Context matters: The impact of unit leadership and empowerment on nurses' organizational commitment. Journal of Nursing Administration, 39(5), 228-235. https://doi.org/10.1097/NNA.0b013e3181a23d2b.

[50] Laschinger, H. K. S., Shamian, J., \& Thomson, D. (2001). Impact of magnet hospital characteristics on nurses' perceptions of trust, burnout, quality of care, and work satisfaction. Nursing economics, 19(5), 209.

[51] Laschinger, H. K. S., Almost, J., \& Tuer-Hodes, D. (2003). Workplace empowerment and magnet hospital characteristics: making the link. Journal of nursing administration, 33(7/8), 410-422. https://doi.org/10.1097/00005110-200307000-00011.

[52] Leiter, M. P., \& Laschinger, H. K. S. (2006). Relationships of work and practice environment to professional burnout: testing a causal model. Nursing research, 55(2), 137-146. https://doi.org/10.1097/00006199-200603000-00009.

[53] Lin, S. Y., Chiang, H. Y., \& Chen, I. L. (2011). Comparing nurses intent to leave or stay: Differences of practice environment perceptions. Nursing \& health sciences, 13(4), 463-467. https://doi.org/10.1111/j.1442-2018.2011.00640.x.

[54] Lin, L., \& Liang, B. A. (2007, January). Addressing the nursing work environment to promote patient safety. In Nursing Forum (Vol. 42, No. 1, pp. 20-30). Blackwell Publishing Inc. https://doi.org/10.1111/j.1744-6198.2007.00062.x.

[55] Manojlovich, M. (2005). Linking the practice environment to nurses' job satisfaction through nurse-physician communication. Journal of Nursing Scholarship, 37(4), 367-373. https://doi.org/10.1111/j.1547-5069.2005.00063.x.

[56] Mark, B. A., Lindley, L., \& Jones, C. B. (2009). Nurse working conditions and nursing unit costs. Policy, politics, \& nursing practice, 10(2), 120-128. https://doi.org/10.1177/1527154409336200.

[57] McCloskey, B. A., \& Diers, D. K. (2005). Effects of New Zealand's health reengineering on nursing and patient outcomes. Medical care, 43(11),

1140-1146. https://doi.org/10.1097/01.mlr.0000182549.85761.cd.

[58] McClure, M. L., \& Hinshaw, A. S. (2002). Magnet hospitals revisited: Attraction and retention of professional nurses. Silver Spring, MD: American Nurses Association.

[59] Mcclure, M. L., Poulin, M. A., Sovie, M. D., \& Wandelt, M. A (1983). Magnet Hospitals: Attraction and Retention of Professional Nurses. American Academy of Nursing. Task Force on Nursing Practice in Hospitals.

[60] Nixon, A. E., Mazzola, J. J., Bauer, J., Krueger, J. R., \& Spector, P. E. (2011). Can work make you sick?

[61] A meta-analysis of the relationships between job stressors and physical symptoms. Work \& Stress, 25(1), 1-22. https://doi.org/10.1080/02678373.2011.569175.

[62] Nurses Assocciation of new Brunkswick (NANB) (2011), Quality Practice Environment for Registered Nurses. Retrieved from: http://www.nanb.nb.ca/downloads/Quality\%20Practice\%20Environ ment $\% 20$ for\%20Registered\%20Nurses_E\%20(1).pdf

[63] Pullon, S. (2008). Competence, respect and trust: Key features of successful interprofessional nurse-doctor relationships. Journal of interprofessional care, 22(2), 133-147. https://doi.org/10.1080/13561820701795069.

[64] Purdy, N., SPENCE LASCHINGER, H. K., Finegan, J., Kerr, M., \& Olivera, F. (2010). Effects of work environments on nurse and patient outcomes. Journal of Nursing Management, 18(8), 901-913. https://doi.org/10.1111/j.1365-2834.2010.01172.x.

[65] Roche, M., Diers, D., Duffield, C., \& Catling-Paull, C. (2010). Violence toward nurses, the work environment, and patient outcomes. Journal of Nursing Scholarship, 42(1), 13-22. https://doi.org/10.1111/j.1547-5069.2009.01321.x.

[66] Roche, M. A., \& Duffield, C. M. (2010). A Comparison of the Nursing Practice Environment in Mental Health and Medical-Surgical Settings. Journal of Nursing Scholarship, 42(2), 195206. https://doi.org/10.1111/j.1547-5069.2010.01348.x.

[67] Rochefort, C. M., Buckeridge, D. L., \& Abrahamowicz, M. (2015) Improving patient safety by optimizing the use of nursing human $\begin{array}{llll}\text { resources. } & \text { Implementation } & \text { Science, } & 10(1),\end{array}$ https://doi.org/10.1186/s13012-015-0278-1.
[68] Schalk, D. M., Bijl, M. L., Halfens, R. J., Hollands, L., \& Cummings, G. G. (2010). Systematic Review Interventions aimed at improving the nursing work environment: a systematic review. Feedback, 10, 14. https://doi.org/10.1186/1748-5908-5-34.

[69] Schmalenberg, C., \& Kramer, M. (2008). Essentials of a productive nurse work environment. Nursing research, 57(1), 2-13. https://doi.org/10.1097/01.NNR.0000280657.04008.2a.

[70] Seago, J. A. (2002). The California experiment: alternatives for minimum nurse-to-patient ratios. Journal of Nursing Administration, 32(1), 48-58. https://doi.org/10.1097/00005110-20020100000012.

[71] Sleutel, M. R. (2000). Climate, culture, context, or work environment? Organizational factors that influence nursing practice. Journal of Nursing Administration, 30(2), 53-58. https://doi.org/10.1097/00005110-200002000-00002.

[72] Smith, H., Tallman, R., \& Kelly, K. (2006). Magnet hospital characteristics and northern Canadian nurses' job satisfaction. Nursing $\begin{array}{llll}\text { leadership } \quad \text { (Toronto, } & \text { Ont.), } & \text { 73-86. }\end{array}$ https://doi.org/10.12927/cjnl.2006.18379.

[73] SPENCE LASCHINGER, H. K., Wilk, P., Cho, J., \& Greco, P. (2009). Empowerment, engagement and perceived effectiveness in nursing work environments: does experience matter?. Journal of Nursing Management, 17 (5), 636-646. https://doi.org/10.1111/j.1365-2834.2008.00907.x.

[74] Sriratanaprapat, J., \& Songwathana, P. (2011). Nurses' Job Satisfaction within the Context of Asian Cultures: A Concept Analysis. $\mathrm{Pa}$ cific Rim International Journal of Nursing Research, 15(1).

[75] Tervo-Heikkinen, T., Partanen, P., Aalto, P., \& Vehviläinen-Julkunen, K. (2008). Nurses' work environment and nursing outcomes: a survey study among Finnish university hospital registered nurses. International Journal of Nursing Practice, 14(5), 357-365. https://doi.org/10.1111/j.1440-172X.2008.00707.x.

[76] Ulrich, B. T., Lavandero, R., Hart, K. A., Woods, D., Leggett, J., \& Taylor, D. (2006). Critical care nurses' work environments: a baseline status report. Critical Care Nurse, 26(5), 46-57.

[77] Upenieks, V. V. (2003). The interrelationship of organizational characteristics of magnet hospitals, nursing leadership, and nursing job satisfaction. The Health Care Manager, 22(2), 83-98. https://doi.org/10.1097/00126450-200304000-00002.

[78] Vahey, D. C., Aiken, L. H., Sloane, D. M., Clarke, S. P., \& Vargas, D. (2004). Nurse burnout and patient satisfaction. Medical care, 42(2 Suppl), https://doi.org/10.1097/01.mlr.0000109126.50398.5a

[79] Van Bogaert, P., Meulemans, H., Clarke, S., Vermeyen, K., \& Van de Heyning, P. (2009). Hospital nurse practice environment, burnout, job outcomes and quality of care: test of a structural equation model. Journal of advanced nursing, 65(10), 2175-2185. https://doi.org/10.1111/j.1365-2648.2009.05082.x.

[80] Weaver, R. (2013). Games, civil war and mutiny: metaphors of conflict for the nurse-doctor relationship in medical television programmes. Nursing inquiry, 20(4), 280-292. https://doi.org/10.1111/nin.12023.

[81] Wolf, G. A., \& Greenhouse, P. K. (2006). A road map for creating a magnet work environment. Journal of Nursing Administration, 36(10), 458-462. https://doi.org/10.1097/00005110-200610000$\underline{00006}$

[82] Zangaro, G. A., \& Soeken, K. L. (2007). A meta-analysis of studies of nurses' job satisfaction. Research in nursing \& health, 30(4), 445-458. https://doi.org/10.1002/nur.20202. 